\title{
A NECESSÁRIA MODULAÇÃo DOS EFEITOS NA DECLARAÇÃO DE INCONSTITUCIONALIDADE DE INCENTIVOS FISCAIS DE ICMS DECORRENTES DA GUERRA FISCAL *
}

\author{
THE NECESSARY MODULATION OF THE EFFECTS IN THE DECLARATION OF \\ UNCONSTITUTIONALITY OF ICMS TAX INCENTIVES ARISING FROM THE HARMFUL TAX \\ COMPETITION
}

Breno Lobato Cardoso**

\begin{abstract}
Resumo: O artigo aborda a questão relacionada a saber se um contribuinte pode vir a ser obrigado a devolver ao erário valores decorrentes de incentivos fiscais de ICMS declarados inconstitucionais pelo Supremo Tribunal Federal. Analisa-se a posição do Supremo Tribunal Federal sobre o assunto, que é no sentido de reconhecer a inconstitucionalidade de leis concessoras de incentivos fiscais feitas sem autorização - unânime - do CONFAZ. Discorre-se sobre os efeitos que essa declaração de inconstitucionalidade opera na esfera jurídica do contribuinte, para concluir ser necessário modular os efeitos da decisão pro futuro, em face do princípio da confiança legítima, de modo a impedir que o contribuinte venha a ser cobrado, de modo retroativo, a devolver os valores incentivados.
\end{abstract}

Palavras-Chave: Guerra fisscal. Confiança legítima. Modulação dos efeitos.

Abstract: The article addresses the question related to whether a taxpayer may be required to return to the public treasury amounts resulting from ICMS tax incentives declared unconstitutional by the Supreme Court. The position of the Supreme Court on the matter, which is to recognize the unconstitutionality of lease laws tax incentives made without permission -unanimous- of CONFAZ. Talks about the effects that this Declaration of unconstitutionality operates in the sphere of legal contributor, to conclude be needed of the effects of the decision modulation pro futuro, in the face of the principle of legitimate expectations, in order to prevent the taxpayer will be charged, so returning the retrospective values encouraged.

Key words: Harmful tax competition. Legitimate expectations. Modulation of the effects.

Sumário: 1. Introdução. 2. A jurisprudência do Supremo Tribunal Federal sobre guerra fiscal. 3. A posição adotada no Brasil a respeito dos efeitos temporais da declaração de inconstitucionalidade. 4. A necessária modulação dos efeitos em face do princípio da proteção a confiança legítima. 5 Conclusões. Referências bibliográficas.

\footnotetext{
*Artigo submetido em 13 fev. 2017 e aceito para publicação em 17 mar. 2018.

${ }^{* *}$ Advogado, Mestrando UFPA, Belém, PA, Brasil.
}

Revista de Finanças Públicas, Tributação e Desenvolvimento - RFPTD, v. 6, n.6, 2018 


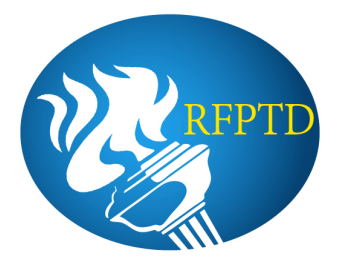

\section{INTRODUÇÃO}

$\mathrm{Na}$ década de 90, uma série de fatores, como o abandono pela União das políticas de incentivos fiscais via SUDAM, SUDENE e SUDECO; a abertura da economia brasileira e uma relativa estabilidade do Real, que deram ensejo a um fluxo crescente de capital estrangeiro viesse para o país em busca de oportunidades; aliado, ainda, a perda de receita estadual decorrente da desoneração das exportações pela Lei Kandir, fez com que os Estados se utilizassem da concessão de incentivos fiscais de ICMS para atrair investimento privado para a sua região, o que ficou conhecido como guerra fiscal.

Não se trata propriamente de uma novidade, pois a utilização dos tributos para atrair investimentos privados desde muito tempo é utilizada, não se limitando aos Estados, pois há municípios e até mesmo países que utilizam dessa fórmula há muitos anos.

O que caracteriza a guerra fiscal "brasileira" é a utilização, de forma generalizada, por parte dos Estados, de incentivos fiscais de ICMS sem autorização do CONFAZ - Conselho Nacional de Política Fazendária.

A LC 24/1975, no seu art. $2^{\circ}, \S 2^{\circ}$, exige, para a concessão de incentivos físcais de ICMS, autorização unânime do CONFAZ, órgão composto por representantes das fazendas estaduais de todos os Estados e do Distrito Federal, presidido por representante do governo federal.

No entanto, essa autorização, dado os interesses conflitantes existentes, é muito difícil de ser obtida, o que, todavia, não impediu os Estados de se lançarem nessa guerra sem a autorização do órgão fazendário.

O tema foi levado a discussão perante o Supremo Tribunal Federal, que construiu uma jurisprudência, de forma reiterada, no sentido de que sem a autorização prévia - e unânime - do CONFAZ, incentivos fiscais de ICMS são inconstitucionais.

No dia 01/06/2011, de forma emblemática, o Supremo Tribunal Federal julgou 12 (doze) ações, de uma só sentada, no qual foram julgadas inconstitucionais leis de vários estados da federação.

Em julgamentos mais recentes, o Supremo Tribunal Federal tem reafirmado a sua posição. Tramita, inclusive, uma proposta de súmula vinculante sobre o tema. 


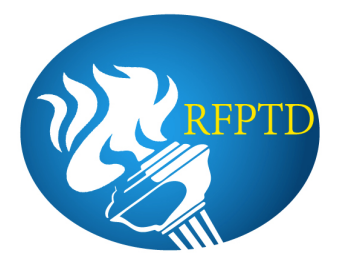

Há iniciativas que buscam por fim a essa guerra, a exemplo da Lei Complementar $n^{\circ}$ 160/2017, que permite a remissão de dívidas decorrentes dessas desonerações inconstitucionais mediante certas condições ligadas a transparência e a não concessão de novos incentivos. A norma possibilita, ainda, a prorrogação dos incentivos vigentes por até 15 (quinze) anos, havendo dúvidas se a norma será capaz de por fim a guerra fiscal.

Nesse cenário, uma questão perturba o mundo jurídico e o ambiente de negócios: tratase de saber se diante de um incentivo fiscal de ICMS declarado inconstitucional pelo Supremo Tribunal Federal, o contribuinte pode vir a ser obrigado a devolver ao erário os valores incentivados?

\section{A JURISPRUDÊNCIA DO SUPREMO TRIBUNAL FEDERAL SOBRE GUERRA FISCAL}

O ICMS, apesar de ser um imposto de competência dos Estados, tem impacto no país inteiro, uma vez que, por sua natureza, incide em operações interestaduais e de importação, razão pela qual é comumente chamada de um imposto de vocação nacional.

Dada essa característica, a Constituição determinou que Lei Complementar viesse regular a forma como, mediante deliberação dos Estados e do Distrito Federal, seriam concedidos e revogados incentivos e benefícios fiscais, de acordo com o art. 155, §2, XII, "g".

A Lei Complementar $n^{\circ} 24 / 1975$ é que regula essa forma e prevê, no seu art. $2^{\circ}, \S 2^{\circ}$, que a concessão de incentivos depende de aprovação unânime dos Estados representados no CONFAZ - Conselho Nacional de Política Fazendária. Já para a revogação de tais benefícios fiscais o quorum é de quatro quintos.

É válido mencionar que o convênio autoriza a concessão do benefício, o qual, no entanto, para a devida observância do princípio da legalidade, não prescinde da lei estadual, que introduz a norma do ordenamento jurídico estadual, a fim de que seja resguardada, ainda, a competência tributária privativa e indelegável do Estado em matéria de ICMS (art. 155, II, CF). 


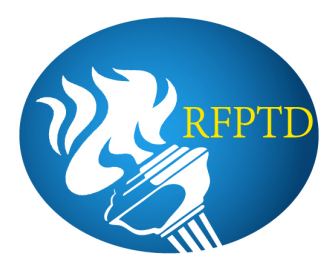

Assim, resta claro que interpretação do art. $4^{\circ}$ da $\operatorname{LC} 24 / 1975^{1}$ deve ser feita em conjunto com o princípio da legalidade, de maneira que a ratificação dos convênios pelo Estado não deve se dar por Decreto do Executivo, mas por norma do Poder Legislativo Estadual ${ }^{2}$.

Essa exigência é reiterada no art. $150, \S 6^{\circ}$ da Constituição, que enuncia, expressamente, a necessidade de lei para introduzir isenções, incentivos ou benefícios fiscais no ordenamento ${ }^{3}$.

Como a unanimidade dentro de um contexto com diversos interesses conflitantes é muito difícil de ser alcançada, os Estados acabaram concedendo incentivos fiscais de ICMS à revelia do CONFAZ, de modo a violar a LC 24/1975, prática que se tornou usual e generalizada, a que se denomina guerra fiscal.

A jurisprudência do Supremo Tribunal Federal se construiu ao longo do tempo no sentido de considerar inconstitucional a concessão de incentivos fiscais de ICMS à revelia do CONFAZ. Veja que em 01/06/2011 o plenário julgou, conforme informativo de jurisprudência ${ }^{\circ}$ $629^{4}$, de uma só vez, 12 (doze) leis estaduais que concediam incentivos fiscais de ICMS sem a autorização, por unanimidade, do CONFAZ, declarando-as inconstitucionais. O posicionamento vem sendo reafirmado, como se verifica do Informativo de Jurisprudência $n^{\circ} 633^{5}$ e $n^{0} 755^{6}$.

Tramita, ainda, no Supremo Tribunal Federal a proposta de súmula vinculante $\mathrm{n}^{\mathrm{o}} 69$, com o seguinte verbete: “Qualquer isenção, incentivo, redução de alíquota ou de base de cálculo, crédito presumido, dispensa de pagamento ou de outro benefício fiscal relativo ao ICMS, concedido sem prévia aprovação em convênio celebrado no âmbito do CONFAZ, é inconstitucional"?.

\footnotetext{
${ }^{1}$ Art. $4^{\circ}$ - Dentro do prazo de 15 (quinze) dias contados da publicação dos convênios no Diário Oficial da União, e independentemente de qualquer outra comunicação, o Poder Executivo de cada Unidade da Federação publicará decreto ratificando ou não os convênios celebrados, considerando-se ratificação tácita dos convênios a falta de manifestação no prazo assinalado neste artigo.

${ }^{2}$ CARRAZA, Roque Antonio. ICMS - $12^{\mathrm{a}}$ Ed - São Paulo: Malheiros, 2007.

${ }^{3}$ CARVALHO, Paulo de Barros. A concessão de isenções, incentivos ou benefícios fiscais no âmbito do ICMS. In: CARVALHO, Paulo de Barros. MARTINS, Ives Gandra da Silva. Guerra fiscal: reflexões sobre a concessão de benefícios no âmbito do ICMS - 2 ed. - São Paulo: Noeses, 2014, p. 38.

${ }_{4}$ SUPREMO TRIBUNAL FEDERAL. Informativo de Jurisprudência $\mathrm{n}^{\circ}$ 629. Disponível em: <<http://www.stf.jus.br//arquivo/informativo/documento/informativo629.htm>>. Acesso: 08 jan. 2016.

5 SUPREMO TRIBUNAL FEDERAL. Informativo de Jurisprudência $\mathrm{n}^{\circ}$ 633. Disponível em : $<<$ http://www.stf.jus.br/portal/jurisprudencia/listarJurisprudencia.asp?s1=\%28incentivo+fiscal $+\mathrm{e}+\mathrm{icms} \% 29 \&$ base $=$ bas eInformativo\&url=http://tinyurl.com/hzvw425>>. Acesso: 14 mar. 2016.

6 SUPREMO TRIBUNAL FEDERAL. Informativo de Jurisprudência $\mathrm{n}^{\mathrm{o}}$ 755. Disponível em : $<<$ http://www.stf.jus.br/portal/jurisprudencia/listarJurisprudencia.asp?s1=\%28incentivo+fiscal $+\mathrm{e}+\mathrm{icms} \% 29 \&$ base $=$ bas eInformativo\&url=http://tinyurl.com/hzvw425>>. Acesso: 14 mar. 2016.

7 SUPREMO TRIBUNAL FEDERAL. Proposta de súmula vinculante $\mathrm{n}^{\mathrm{o}}$ 69. Disponível em: $<<\mathrm{http}: / /$ www.stf.jus.br/portal/processo/verProcessoAndamento.asp?incidente=4222438>>. Acesso: 08 jan. 2016.
} 


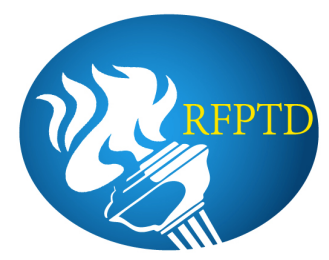

O fundamento utilizado pelo Supremo Tribunal Federal é a suposta violação ao art.155, $\S 2^{\circ}$, XII, “g” da Constituição: "XII - cabe à lei complementar (...) g) regular a forma como, mediante deliberação dos Estados e do Distrito Federal, isenções, incentivos e benefícios fiscais serão concedidos e revogados" ${ }^{\prime 8}$.

Interessante notar que o disposto constitucional em questão delegou a lei complementar o papel de regular a forma de concessão de incentivo fiscal de ICMS, de maneira que, de fato, o dispositivo que exige a unanimidade é de caráter infraconstitucional, assente no art. $2^{\circ}, \S 2^{\circ}$ da LC 24/1976.

Portanto, verifica-se que se trata de suposta ofensa meramente reflexa a Constituição, o que, seguindo a jurisprudência do próprio Tribunal, afastaria a sua competência para a análise do caso $^{9}$.

\section{A POSIÇÃO ADOTADA NO BRASIL A RESPEITO DOS EFEITOS TEMPORAIS DA DECLARAÇÃO DE INCONSTITUCIONALIDADE}

São duas as principais correntes sobre os efeitos da declaração de constitucionalidade, uma que sustenta a anulabilidade da norma declarada inconstitucional, portanto, de natureza constitutiva e ex nunc, propalada por Kelsen e outra que defende a nulidade da norma declarada inconstitucional, em consequência, de natureza declaratória e ex tunc, cujo principal defensor foi Marshall.

De acordo com os ensinamentos de Kelsen, uma lei que contrarie a Constituição pode ser revogada não só pelo processo usual, segundo o princípio lei posterior derroga a anterior, mas também por um processo especial, previsto na Constituição, cuja competência cabe a um órgão jurídico. No entanto, enquanto a lei não foi revogada, tem der considerada válida ${ }^{10}$.

\footnotetext{
${ }^{8}$ Para críticas a esse posicionamento, fundadas na não recepção do art. $2^{\circ}$, $2^{\circ}$ da LC $24 / 1975$ pela Constituição, ver: SCAFF, Fernando Facury. Novas batalhas da guerra fiscal e a emenda 87. In: SCAFF, Fernando Facury. Crônicas de direito financeiro: tributação, guerra fiscal e políticas públicas. $1^{a}$ ed. São Paulo: Conjur Editorial, 2016, p. 206210. MACHADO, Hugo de Brito. Proibição da guerra fiscal e a redução das desigualdades regionais. In: Grandes questões atuais do direito tributário. $15^{\circ}$ volume. São Paulo: Dialética, 2011, p. 54.

${ }^{9}$ Sobre o tema confere-se: ARE 974338 AgR, Relator(a): Min. EDSON FACHIN, Primeira Turma, julgado em 28/10/2016, PROCESSO ELETRÔNICO DJe-244 DIVULG 17-11-2016 PUBLIC 18-11-2016; ARE 946671 AgR, Relator(a): Min. LUIZ FUX, Primeira Turma, julgado em 14/10/2016, PROCESSO ELETRÔNICO DJe-234 DIVULG 03-11-2016 PUBLIC 04-11-2016; RE 607058 AgR, Relator(a): Min. ROBERTO BARROSO, Primeira Turma, julgado em 30/09/2016, PROCESSO ELETRÔNICO DJe-221 DIVULG 17-10-2016 PUBLIC 18-10-2016.

${ }^{10}$ KELSEN, Hans. Teoria pura do direito (tradução João Baptista Machado) - $6^{a}$ ed. - São Paulo: Martins Fontes, 1998, p. 300 .
} 


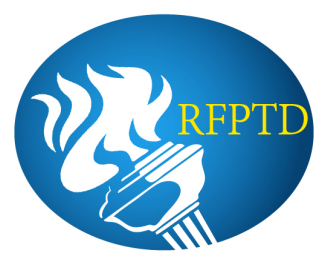

Já Marshall, que presidiu o julgamento de Marbury x Madison, realizado em 1803 pela Suprema Corte dos Estados Unidos, defende que todos aqueles que formularam constituições escritas a consideram como a lei fundamental da nação e, consequentemente, sustentam a teoria de que de que todo ato de governo ou da legislatura, que a viole, é nulo. Diante de um ato nulo, não podem os Tribunais atribuir-lhe efeitos ${ }^{11}$.

A teoria da nulidade da norma foi amplamente acolhida no Direito brasileiro, tendo Rui Barbosa assim pronunciado em obra clássica sobre a inconstitucionalidade das leis: "Aqui posso registrar, pois, mais estas premissas: Toda medida, legislativa, ou executiva, que desrespeitar preceitos constitucionais, é, dê sua essência, nulla"12.

Zeno Veloso, após discorrer sobre o posicionamento de vários doutrinadores que controvertem sobre o assunto, informa que a posição dominante no Brasil é a que reconhece, como regra, a nulidade de pleno direito a lei declarada inconstitucional ${ }^{13}$.

Para ele, "a declaração de inconstitucionalidade de uma lei alcança, inclusive, os atos pretéritos com base nela praticados"

Também para Luís Roberto Barroso nenhum ato legislativo contrário a Constituição pode ser válido e a falta de validade traz como consequência a nulidade ou anulabilidade. No caso da lei inconstitucional, aplica-se a sanção mais grave, que é a nulidade. Ele argumenta que se a Constituição é a lei suprema, admitir a aplicação de uma lei com ela incompatível é violar sua supremacia ${ }^{15}$.

Como consequência natural da teoria da nulidade, explica o hoje Ministro do Supremo Tribunal Federal, que a decisão que reconhece a inconstitucionalidade tem caráter declaratório, cujos efeitos são retroativos, colhendo a lei desde o momento de sua entrada no mundo jurídico. Disso resulta, como regra, que não são admitidos efeitos válidos a lei inconstitucional ${ }^{16}$.

\footnotetext{
${ }^{11}$ SUPREME COURT OF THE UNITED STATES. Willian Marbury v. James Madison, Secretary of State of the United States. $\quad$ Februrary, $1803 . \quad$ Disponível em: $<$ http://law2.umkc.edu/faculty/projects/ftrials/conlaw/marbury.HTML>. Acesso: 22 dez. 2016, p. 5.

${ }^{12}$ BARBOSA, Rui. Os actos inconstitucionais do Congresso e do Executivo ante a justiça federal. Companhia Impressora: Capital Federal, 1893, p. 46.

${ }^{13}$ VELOSO, Zeno. Controle jurisdicional de constitucionalidade: atualizado conforme as Leis 9.868 de $10.11 .1999 \mathrm{e}$ 9.882 de 03.12.1999 - 3 ed. - Belo Horizonte: Del Rey Editora, 2003, p. 184.

${ }^{14}$ Ibidem, p. 184.

${ }^{15}$ BARROSO, Luís Roberto. O controle de constitucionalidade no direito brasileiro $-2^{\mathrm{a}}$ ed - São Paulo: Saraiva, 2006, p. 15-16.

${ }^{16}$ Ibidem, p. 16.
} 


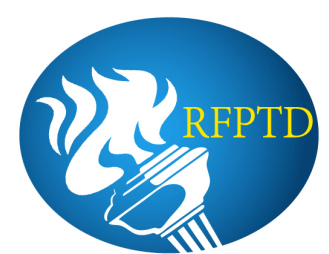

É possível constatar que ao tomar como regra a natureza declaratória e os efeitos retroativos à declaração de inconstitucionalidade, há uma aproximação da corrente majoritária com a teoria da nulidade propalada por Marshall.

Em sentido contrário, aproximando-se das ideias trabalhadas por Kelsen, está Hugo de Brito Machado ${ }^{17}$, para quem a atividade desenvolvida pelo Supremo Tribunal ao declarar uma norma inconstitucional, retirando-a, assim, do ordenamento jurídico, é de natureza legislativa e não jurisdicional, pois se trata de prescrição jurídica abstrata e geral. Assim, ele sustenta que os efeitos dessa decisão no tempo devem ser submetidos ao mesmo regime jurídico dos atos legislativos, sendo a regra a sua irretroatividade e só de forma excepcional a retroação dos efeitos, que somente poderia ser admitida quando favorável ao cidadão.

Fernado Facury Scaff $^{18}$, com apoio nas ideias de Cappelleti ${ }^{19}$, adota uma posição intermediária, pois defende que a declaração de inconstitucionalidade de uma lei não pode afetar situações consolidadas há longo tempo com terceiros de boa-fé que a obedeceram. Quanto mais dilargado este prazo, maior a chance de existirem situações consolidadas cuja reversibilidade se tornará difícil e injusta.

Ele não está a defender que a declaração de inconstitucionalidade não retroage. Argumenta, apenas, que os efeitos retroativos não deveriam operar em situações pontuais, cujos efeitos consolidados das situações concretas possam levar a uma injustiça ainda maior do que a singela e genérica retroação ${ }^{20}$.

Ao se pesquisar a jurisprudência do Supremo Tribunal Federal, constata-se que a posição dominante é que a declaração de inconstitucionalidade tem eficácia retroativa, conforme ficou assentado no julgamento da Ação Direta de Inconstitucionalidade ${ }^{\circ}$ 652:

AÇÃO DIRETA DE INCONSTITUCIONALIDADE - CONTROLE NORMATIVO ABSTRATO - NATUREZA DO ATO INCONSTITUCIONAL - DECLARAÇÃO DE INCONSTITUCIONALIDADE - EFICACIA RETROATIVA - O SUPREMO TRIBUNAL FEDERAL COMO "LEGISLADOR NEGATIVO" - REVOGAÇÃO SUPERVENIENTE DO ATO NORMATIVO IMPUGNADO - PRERROGATIVA INSTITUCIONAL DO PODER PÚBLICO - AUSÊNCIA DE EFEITOS RESIDUAIS CONCRETOS - PREJUDICIALIDADE. - O REPUDIO AO ATO INCONSTITUCIONAL DECORRE, EM ESSENCIA, DO PRINCÍPIO QUE,

\footnotetext{
${ }^{17}$ MACHADO, Hugo de Brito. Declaração de inconstitucionalidade e direito intertemporal. In: Revista Dialética de Direito Tributário $\mathrm{n}^{\mathrm{0}} 57$, p. $72-87$.

${ }^{18}$ SCAFF, Fernando Facury. A responsabilidade tributária e a inconstitucionalidade da guerra fiscal. In: Grandes questões atuais do direito tributário. $15^{\circ}$ volume. São Paulo: Dialética, 2011, p. 54. Ver também: SCAFF, Fernando Facury. Guerra Fiscal e Súmula Vinculante: entre o Formalismo e o Realismo. ROCHA, Valdir de Oliveira. Grandes Questões Atuais do Direito Tributário, v. 18. São Paulo: Dialética, 2014. p. 90-115.

${ }^{19}$ CAPPELLETTI, Mauro. O controle judicial de constitucionalidade das leis no direito comparado. Tradução de Aroldo Plínio Gonçalves. Porto Alegre, Fabris, 1984.

${ }^{20}$ SCAFF, op. cit. (2011), p. 56.
} 


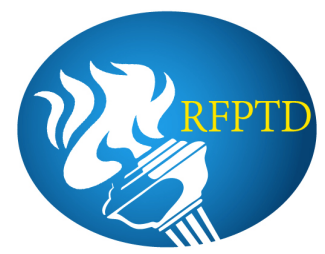

FUNDADO NA NECESSIDADE DE PRESERVAR A UNIDADE DA ORDEM JURÍDICA NACIONAL, CONSAGRA A SUPREMACIA DA CONSTITUIÇÃO. ESSE POSTULADO FUNDAMENTAL DE NOSSO ORDENAMENTO NORMATIVO IMPÕE QUE PRECEITOS REVESTIDOS DE "MENOR" GRAU DE POSITIVIDADE JURÍDICA GUARDEM, "NECESSARIAMENTE", RELAÇÃO DE CONFORMIDADE VERTICAL COM AS REGRAS INSCRITAS NA CARTA POLITICA, SOB PENA DE INEFICACIA E DE CONSEQUENTE INAPLICABILIDADE. ATOS INCONSTITUCIONAIS SÃO, POR ISSO MESMO, NULOS E DESTITUIDOS, EM CONSEQUENCIA, DE QUALQUER CARGA DE EFICACIA JURÍDICA. - A DECLARAÇÃO DE INCONSTITUCIONALIDADE DE UMA LEI ALCANCA, INCLUSIVE, OS ATOS PRETERITOS COM BASE NELA PRATICADOS, EIS QUE O RECONHECIMENTO DESSE SUPREMO VÍCIO JURÍDICO, QUE INQUINA DE TOTAL NULIDADE OS ATOS EMANADOS DO PODER PÚBLICO, DESAMPARA AS SITUAÇÕES CONSTITUIDAS SOB SUA EGIDE E INIBE - ANTE A SUA INAPTIDAO PARA PRODUZIR EFEITOS JURIDICOS VALIDOS - A POSSIBILIDADE DE INVOCAÇÃO DE QUALQUER DIREITO. - A DECLARAÇÃO DE INCONSTITUCIONALIDADE EM TESE ENCERRA UM JUÍZO DE EXCLUSAO, QUE, FUNDADO NUMA COMPETÊNCIA DE REJEIÇÃO DEFERIDA AO SUPREMO TRIBUNAL FEDERAL, CONSISTE EM REMOVER DO ORDENAMENTO POSITIVO A MANIFESTAÇÃO ESTATAL INVALIDA E DESCONFORME AO MODELO PLASMADO NA CARTA POLITICA, COM TODAS AS CONSEQUENCIAS DAI DECORRENTES, INCLUSIVE A PLENA RESTAURAÇÃO DE EFICACIA DAS LEIS E DAS NORMAS AFETADAS PELO ATO DECLARADO INCONSTITUCIONAL. ESSE PODER EXCEPCIONAL - QUE EXTRAI A SUA AUTORIDADE DA PROPRIA CARTA POLITICA - CONVERTE O SUPREMO TRIBUNAL FEDERAL EM VERDADEIRO LEGISLADOR NEGATIVO. - A MERA INSTAURAÇÃO DO PROCESSO DE FISCALIZAÇÃO NORMATIVA ABSTRATA NÃO IMPEDE O EXERCÍCIO, PELO ÓRGÃO ESTATAL COMPETENTE, DA PRERROGATIVA DE PRATICAR OS ATOS QUE SE INSEREM NA ESFERA DE SUAS ATRIBUIÇÕES INSTITUCIONAIS: O DE CRIAR LEIS E O DE REVOGA-LAS. O AJUIZAMENTO DA AÇÃO DIRETA DE INCONSTITUCIONALIDADE NÃO TEM, POIS, O CONDAO DE SUSPENDER A TRAMITAÇÃO DE PROCEDIMENTOS LEGISLATIVOS OU DE REFORMA CONSTITUCIONAL QUE OBJETIVEM A REVOGAÇÃO DE LEIS OU ATOS NORMATIVOS CUJA VALIDADE JURÍDICA ESTEJA SOB EXAME DA CORTE, EM SEDE DE CONTROLE CONCENTRADO. - A SUSPENSÃO CAUTELAR DA EFICACIA DO ATO NORMATIVO IMPUGNADO EM AÇÃO DIRETA - NÃO OBSTANTE RESTAURE, PROVISORIAMENTE, A APLICABILIDADE DA LEGISLAÇÃO ANTERIOR POR ELE REVOGADA - NÃO INIBE O PODER PUPLICO DE EDITAR NOVO ATO ESTATAL, OBSERVADOS OS PARAMETROS INSTITUIDOS PELO SISTEMA DE DIREITO POSITIVO. - A REVOGAÇÃO SUPERVENIENTE DO ATO NORMATIVO IMPUGNADO, EM SEDE DE CONTROLE CONCENTRADO DE CONSTITUCIONALIDADE, IMPEDE, DESDE QUE INEXISTENTES QUAISQUER EFEITOS RESIDUAIS CONCRETOS, O PROSSEGUIMENTO DA PROPRIA AÇÃO DIRETA ${ }^{21}$. (Grifou-se)

Na prática, todavia, algumas situações se tornam irreversíveis e exigem um tratamento peculiar, mas que tem caráter excepcional. A experiência demonstrou a necessidade de oferecer temperamentos ao reconhecimento dos efeitos retroativos à declaração de inconstitucionalidade,

\footnotetext{
${ }^{21}$ SUPREMO TRIBUNAL FEDERAL. ADI 652, Relator(a): Min. CELSO DE MELLO, Tribunal Pleno, julgado em 02/04/1992, DJ 02-04-1993 PP-05615 EMENT VOL-01698-03 PP-00610 RTJ VOL-00146-02 PP-00461.
}

Revista de Finanças Públicas, Tributação e Desenvolvimento - RFPTD, v. 6, n.6, 2018 


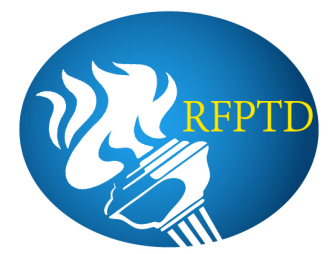

o que levou ao reconhecimento de exceções a regra geral em nome de valores como boa-fé, justiça e segurança jurídica ${ }^{22}$.

Em 1982, o Supremo Tribunal Federal, no RE $78533^{23}$, com base no princípio da boa-fé e na teoria da aparência, deixou de invalidar atos praticados por funcionário investido em cargo público com base em lei que veio a ser declarada inconstitucional.

Nas discussões da Assembleia Constituinte o tema veio à pauta, sendo apresentada uma proposta que permitia que o Supremo Tribunal Federal determinasse se a declaração de inconstitucionalidade retroagiria, ou não. A proposta foi rejeitada. Durante o processo de discussão da revisão constitucional, novamente o assunto veio a debate e, novamente, não foi $\operatorname{aprovado}^{24}$.

Já em 1994, ao tratar sobre recebimento de remuneração indevida por servidores no RE $122202^{25}$, decidiu o Supremo Tribunal Federal que as quantias recebidas não deveriam ser devolvidas, mas que também não seriam mais pagas após o reconhecimento da inconstitucionalidade.

Contudo, em 1999, o Congresso aprovou a lei $n^{\circ}$ 9.868, que no seu art. 27 introduz, de modo formal, no ordenamento jurídico, a possibilidade do Supremo Tribunal Federal modular os efeitos da declaração de inconstitucionalidade, veja:

Art. 27. Ao declarar a inconstitucionalidade de lei ou ato normativo, e tendo em vista razões de segurança jurídica ou de excepcional interesse social, poderá o Supremo Tribunal Federal, por maioria de dois terços de seus membros, restringir os efeitos

\footnotetext{
${ }^{22}$ BARROSO, op.cit., p. 16-21.

23 ADMINISTRATIVO. FUNCIONÁRIO DE FATO. INVESTIDURA BASEADA EM NORMA POSTERIORMENTE DECLARADA INCONSTITUCIONAL. A NULIDADE NÃO ENVOLVE UMA DAS FASES DE ATO COMPLEXO, DE MERA EXECUÇÃO DE ORDEM LEGITIMA, COM A SUA CONSEQUENCIA NORMAL E ROTINEIRA. APARENCIA DE LEGALIDADE E INEXISTENNCIA DE PREJUIZO. RECURSO EXTRAORDINÁRIO, PELA LETRA "C" DO ART. 119, III, DA CONSTITUIÇÃO, NÃO CONHECIDO. (RE 78533, Relator(a): Min. FIRMINO PAZ, Relator(a) p/ Acórdão: Min. DÉCIO MIRANDA, Segunda Turma, julgado em 13/11/1981, DJ 26-02-1982 PP-01290 EMENT VOL-01243-01 PP-00090 RTJ VOL-00100-03 PP01086)

${ }_{25}^{24}$ BARROSO, op. cit., p. 23.

${ }_{25}$ EMENTA: - RECURSO EXTRAORDINÁRIO. EFEITOS DA DECLARAÇÃO DE INCONSTITUCIONALIDADE EM TESE PELO SUPREMO TRIBUNAL FEDERAL. ALEGAÇÃO DE DIREITO ADQUIRIDO. Acórdão que prestigiou lei estadual a revelia da declaração de inconstitucionalidade desta ultima pelo Supremo. Subsistencia de pagamento de gratificação mesmo após a decisão erga omnes da corte. Jurisprudência do STF no sentido de que a retribuição declarada inconstitucional não e de ser devolvida no periodo de validade inquestionada da lei de origem - mas tampouco paga após a declaração de inconstitucionalidade. Recurso $\quad$ extraordinário $\quad$ provido em parte. (RE 122202, Relator(a): Min. FRANCISCO REZEK, Segunda Turma, julgado em 10/08/1993, DJ 08-04-1994 PP07243 EMENT VOL-01739-05 PP-00945)
} 


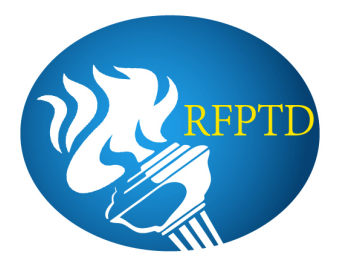

daquela declaração ou decidir que ela só tenha eficácia a partir de seu trânsito em julgado ou de outro momento que venha a ser fixado ${ }^{26}$.

A constitucionalidade do dispositivo legal é questionada na Ação Direta de Inconstitucionalidade $\mathrm{n}^{\mathrm{o}}$ 2258, movida pela Ordem dos Advogados do Brasil, sob a alegação de que seria necessária uma emenda a Constituição ${ }^{27}$.

Após o voto pela inconstitucionalidade do Ministro Sepulveda Pertence em 16/08/2007, a Ministra Presidente Carmen Lúcia pediu vistas, devolvendo os autos para julgamento $11 / 02 / 2016^{28}$. No entanto, até o momento, o feito não foi julgado como se depreende do seu andamento processual ${ }^{29}$.

Tendo em conta que, como exposto acima, a Suprema Corte já concedia temperamentos aos efeitos retroativos da declaração de inconstitucionalidade mesmo antes da mudança legislativa e que a técnica já foi por diversas vezas utilizada, é improvável que o dispositivo venha a ser declarado inconstitucional pelo Plenário.

Ao comentar esse dispositivo legal Zeno Veloso ${ }^{30}$ assevera que se trata de uma circunstância anormal, extraordinária. A regra continua sendo a da eficácia ex tunc da declaração de inconstitucionalidade. Porém, havendo motivos graves, razões de segurança jurídica ou para atender situação de excepcional interesse social, admite-se que pelo voto de 2/3 dos Ministros se restrinja os efeitos da declaração de inconstitucionalidade ou decida que ela só produzirá efeito a partir de determinada data.

Essa exceção e regra geral aproxima-se da teoria da anulabilidade desenvolvido por Kelsen, o que permite concluir que no Brasil adota uma posição intermediária entre as duas principais correntes teóricas a respeito dos efeitos temporais da declaração de inconstitucionalidade.

Há, ainda, a introdução de técnicas de julgamento, que também representam temperamentos a teoria da nulidade, pois envolvem um juízo de inconstitucionalidade sem nulidade ou efeitos ex tunc, a exemplo da declaração de incompatibilidade da norma com a

\footnotetext{
${ }^{26}$ BRASIL. Presidência da República. Casa Civil. Subchefia de Assuntos Jurídicos. Lei n ${ }^{\circ} 9.868$, de 10 de novembro de 1999. Disponível em: <http://www.planalto.gov.br/ccivil_03/leis/L9868.htm>. Acesso: 13 set. 2016.

${ }^{27}$ BARROSO, op.cit., p. 24.

${ }^{28}$ É espantoso o tempo em que o processo ficou com vistas para a Ministra Carmen Lúcia.

29 SUPREMO TRIBUNAL FEDERAL. Andamento processual da ADI 2258. Disponível em: < http://www.stf.jus.br/portal/processo/verProcessoAndamento.asp?incidente=1835254>. Acesso: 25 jan., 2017.

${ }^{30}$ VELOSO, op. cit., p. 195.
} 


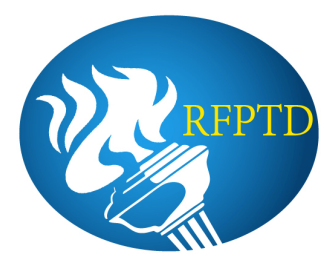

Constituição sem pronúncia de nulidade, a declaração da norma "ainda constitucional", interpretação conforme e a declaração de inconstitucionalidade sem redução do texto ${ }^{31}$.

\section{A NECESSÁRIA MOdULAÇÃo dOS EFEITOS EM FACE DO PRINCÍPIO DA PROTEÇÃO A CONFIANÇA LEGÍTIMA}

Como visto acima, mesmo antes da lei 9.868/1999, o Supremo Tribunal Federal, em casos excepcionais, já oferecia temperamentos a teoria da nulidade e não concedia eficácia retroativa há alguns casos.

Com a mencionada lei, positivou-se no ordenamento jurídico brasileiro, de forma expressa, a possibilidade de modulação dos efeitos da decisão que declara a inconstitucionalidade de lei ou ato normativo, tendo em vista, nos termos do art. 27: "razões de segurança jurídica ou de excepcional interesse social".

A questão é: quando modular os efeitos?

Para isso, é necessário fazer uma pequena incursão pelo significado do princípio da segurança jurídica e pela sua dimensão de proteção à confiança legítima.

Para Paulo de Barros Carvalho o direito positivo é formado, única e exclusivamente, por normas jurídicas, sendo uma construção cultural que carrega consigo uma porção axiológica, isto é, de valores, que são depositados pelo legislador (consciente ou inconscientemente) na linguagem do direito posto. Para ele, quando se está diante de uma norma com um vetor axiológico forte, estaremos diante de um princípio $^{32}, 33$.

De acordo com o seu pensamento, a segurança jurídica seria uma norma-princípio, na verdade um sobreprincípio, na medida em que surge a partir da conjunção de vários princípios, tais como o da legalidade, anterioridade, igualdade, irretroatividade, universalidade da jurisdição e outros ${ }^{34}$.

\footnotetext{
${ }^{31}$ BARROSO, p. 22.

32 CARVALHO, Paulo de Barros. O princípio da segurança jurídica em matéria tributária. Disponível em: $<$ http://www.revistas.usp.br/rfdusp/article/download/67584/70194>. Acesso: 04 jan. 2017, p. 166.

33 Alexy traz um conceito mais preciso sobre princípios, entendidos como mandamentos de otimização, ou seja, normas que podem ser satisfeitas em graus variados, devendo ser aplicada na maior medida possível dentro das possibilidades fáticas e jurídicas (ALEXY, Robert. Teoria dos direitos fundamentais (tradução Virgilio Afonso da Silva) - 5a edição. São Paulo: Malheiros, 2008, p. 90-91)

${ }^{34}$ CARVALHO, op.cit., p. 173-175.
} 


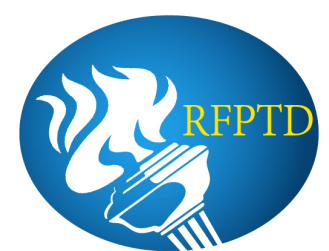

Importante deixar claro que princípio é norma, com todas as implicações que esta proposição venha suscitar ${ }^{35}$, o que significa, portanto, que tem força obrigatória.

Pérez Luño sustenta que a função e o alcance da segurança jurídica dependem das lutas políticas e das vicissitudes culturais de cada tipo de sociedade, sendo um valor estritamente ligado ao Estado de Direito, que se concretiza em exigências objetivas de correção estrutural (formulação adequada das normas do ordenamento jurídico) e funcional (cumprimento do direito por seus destinatários e especialmente pelos órgãos encarregados de sua aplicação) ${ }^{36}$.

Junto com essas exigências objetivas se apresentam exigências de ordem subjetiva decorrente da certeza do direito, com a proteção a situações pessoais e garantias estruturais e funcionais da segurança objetiva ${ }^{37}$.

Também traçando uma diferença entre dimensão objetiva e subjetiva da segurança jurídica está Canotilho, para quem, em geral, considera-se que a segurança jurídica está conexionada com elementos objetivos da ordem jurídica - garantia de estabilidade jurídica, segurança de orientação e realização do direito -, enquanto a proteção da confiança se prende mais aos componentes subjetivos da segurança, designadamente a calculabilidade e previsibilidade dos indivíduos em relação aos efeitos dos atos ${ }^{38}$.

Para Heleno Taveira Torres ${ }^{39}$ o princípio da segurança jurídica encontra fundamento no preâmbulo da Constituição, seus arts. $5^{\circ}$, caput e $\S 2^{\circ}, 150$, assumindo caráter de nítida garantia fundamental e, portanto, protegida pelo art. $60, \S 4^{\circ}$, que no seu aspecto subjetivo pode ser definido como princípio da confiança legítima ${ }^{40}$.

De acordo com o doutrinador, o modelo do garantismo tributário brasileiro, além de todas as garantias expressas, conta com a incorporação integral do princípio da segurança

\footnotetext{
${ }^{35}$ Ibidem, p. 168.

${ }^{36}$ LUÑO, Antonio-Enrique Pérez. La seguridade jurídica: uma garantia del derecho y la justicia. Disponível em: $<$ http://e-spacio.uned.es/fez/eserv/bibliuned:BFD-2000-15-48A09575/PDF>. Acesso. 04 jan. 2017, p. 26-28.

${ }^{37}$ Ibidem, p. 28.

38 CANOTILHO, José Joaquim Gomes. Direito Constitucional e Teoria da Constituição, Coimbra, Livraria Almedina, 2000, p. 256.

39 TORRES, Heleno Taveira. Direito constitucional tributário e segurança jurídica: metódica da segurança jurídica do sistema constitucional tributário - São Paulo: Editora Revista dos Tribunais, 2011, p. 17-18.

${ }^{40}$ Para um maior aprofundamento a respeito da noção do estatuto do contribuinte, vale a pena conferir artigo onde o autor da dissertação apresenta um rol (não exaustivo) dos direitos fundamentais do contribuinte, no qual o princípio da segurança jurídica aparece como direito fundamental implícito: CARDOSO, Breno Lobato. Direitos fundamentais e tributação. In: Revista Fórum de Direito Tributário - ano 13 - n. 78. Nov. / Dez. 2015 - Belo Horizonte, p. 173-187.
} 


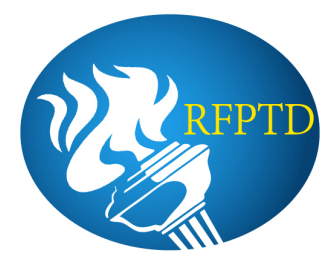

jurídica e seus subprincípios implícitos, segundo as funções de certeza, estabilidade sistêmica e proteção à confiança legítima ${ }^{41}$.

É sobre esse aspecto subjetivo da segurança jurídica ou, se preferir, proteção à confiança legítima, que se pretende ater com mais detalhes, que para Heleno Taveira Torres consiste na "garantia de previsibilidade gerada pelo sistema e esperada pelos particulares", seja qual for a função envolvida (legislativa, executiva ou judicial) ${ }^{42},{ }^{43}$.

Como a confiança é um estado psicológico, para que possa ter eficácia jurídica, deverá revelar-se, objetivar-se de algum modo, não sendo suficiente vínculo fundado em simples expectativa, suposição ou esperança. Nessa análise, a confiança legítima guarda íntima relação com a boa-fé objetiva ${ }^{44}$.

Em síntese, tem se exigido para comprovar a confiança legítima alguns requisitos, a saber: situação passível de proteção, legitimidade da conduta de quem alega a eficácia da confiança; titularidade; e ato de órgão de autoridade pública que contraria o direito exercido em estado de confiança. A situação passível de proteção exige a demonstração de uma situação material a partir de atos de órgãos ou autoridades públicas reveladores de confiança. A legitimidade da conduta exige que a mesma seja lícita, além de pautada pela comprovada presunção de validade e de boa-fé objetiva. Por titularidade entende-se que a confiança a ser protegida deve decorrer de ato constitutivo de direito que exteriorize, de modo vinculante para o interessado, um estado de confiança sobre certo direito legítimo. Já o ato de órgão ou autoridade pública denota uma necessária proteção frente à atuação estatal ${ }^{45}$.

Como se demonstra, o princípio da proteção da confiança legítima garante o cidadão contra modificações substanciais inesperadas, como também daqueles casos cuja permanência de certas situações jurídicas, pelo decurso do tempo ou pela prática continuada da administração já não mais autorize a sua revogação ou anulação do ato administrativo, para fazer valer uma legalidade incongruente com a confiabilidade adquirida ${ }^{46}$.

\footnotetext{
${ }^{41}$ TORRES, op. cit, p. 19.

42 Ibidem, p. 209-211.

${ }^{43}$ Celso Antônio Bandeira de Mello ensina que o princípio da confiança legítima tem aplicação em todos os ramos do Direito e são invocáveis perante condutas estatais em quaisquer de suas esferas: legislativa, administrativa ou jurisdicionais. Para um maior aprofundamento: BANDEIRA DE MELLO, Celso Antônio. Segurança jurídica, boafé e confiança legítima. In: BENEVIDES, Maria Victoria de Mesquita; BERCOVICI, Gilberto; MELO, Claudineu de (org.). Direitos humanos, democracia e república. Homenagem a Fábio Konder Comparato. São Paulo: Quartier Latin, 2009, p. 221.

${ }^{44}$ TORRES, op.cit., p. 211.

${ }^{45}$ Ibidem, p. 215-216.

${ }^{46}$ Ibidem, p. 216.
} 


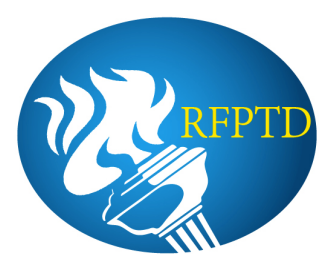

Com base nesse entendimento, ao tratar de benefícios fiscais que supostamente não atendem requisitos legais, sustenta Heleno Taveira Torres que, atendida certas circunstâncias, o princípio da confiança legítima serve, pelo menos, para autorizar a revogação ou anulação com efeitos ex nunc, veja:

Em face desse entendimento, a Administração Pública, que poderia sentir-se compelida a revogar atos que outorgaram benefícios fiscais ou direitos a contribuintes, à suposição que não atenderam requisitos legais; quando verificado que persistia sentimento de confiança legítima, apurado a partir de elementos objetivos, como atendimento periódico de todas as exigências pela Administração e reconhecimento de conduta de boa-fé no contínuo temporal, e que o ato de revogação ou anulação implicaria afetação ao princípio de confiança legítima, ainda que não se possa admitir a continuidade do aproveitamento da vantagem, a força desse princípio deve servir, quando menos, para autorizar revogação ou nulidade com efeitos ex nunc, admitida a convalidação das situações passadas, mas, em qualquer hipótese, sem efeito retroativo para qualquer exigência gravosa, inclusive sanções ${ }^{47}$

Humberto Ávila ${ }^{48}$ também entende a proteção da confiança como dimensão subjetiva da segurança jurídica, princípio que serve de instrumento de defesa de interesses individuais nos casos em que o particular, não sendo protegido pelo direito adquirido ou pelo ato jurídico perfeito, em qualquer âmbito, inclusive no tributário, exerce sua liberdade confiando na validade (ou aparência de validade) de um ato normativo geral ou individual e, posteriormente, tem a sua confiança frustrada pela descontinuidade da vigência ou de seus efeitos, quer por revogação ou anulação.

Para ele, a proteção à confiança é mais do que uma dimensão individual e concreta do princípio da segurança jurídica, pois se fundamenta também nos direitos fundamentais individuais, como a liberdade e de exercício de atividade econômica, que juntamente com o Estado de Direito protegem a confiança colocada em prática pelo cidadão com base causal tanto nas normas jurídicas quanto na credibilidade da atuação estatal, o que adquire ainda maior relevância no âmbito do direito tributário ${ }^{49}$.

Interessante notar que o contribuinte não age com base em normas futuras. Ele o faz com base nas normas presentes. E justamente porque os direitos fundamentais passam a ser medida para a protetividade da confiança é que ocorre uma inversão do ônus argumentativo: "não é o contribuinte que deve encontrar uma razão para afastar os efeitos pretéritos da nova

\footnotetext{
${ }^{47}$ Ibidem, p. 224.

48 ÁVILA, Humberto. Segurança jurídica: entre permanência, mudança e realização no direito tributário - 2 ed. São Paulo: Malheiros, 2012, p. 366.

${ }^{49}$ Ibidem, p. 371-372.
} 


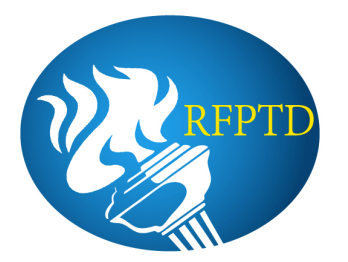

orientação normativa, mas, sim, o Estado, que deve ter uma justificativa proporcional para a restrição de direitos fundamentais" ${ }^{\text {, }}$.

Heleno Taveira Torres levanta que no Brasil o art. 146 do $\mathrm{CTN}^{51}$, ${ }^{52}$, que é aplicável às modificações aos critérios do lançamento introduzidos por atos administrativos ou decisões judiciais, inclusive aqueles de controle de constitucionalidade, consagra um típico efeito ex nunc, de maneira a proibir efeitos retroativos a modificação dos critérios jurídicos do lançamento tributário que sejam prejudiciais ao contribuinte como decorrência, ainda, da proibição de comportamento contraditório ${ }^{53}$.

Sobre essa ligação entre a proteção à confiança legítima e a proibição do comportamento contraditório, o posicionamento de José Casalta Nabais é no sentido de que uma expressão do princípio da proteção da confiança é a que se manifesta através da boa-fé, enquanto proibição ao venire contra factum proprium, que embora tradicionalmente pensada para as relações jurídico-privadas, também vale para as relações jurídico-públicas e, designadamente, nas relações entre o fisco e contribuinte ${ }^{54}, 55$.

Dessa forma, de acordo com a posição de Heleno Taveira Torres, numa eventual declaração de inconstitucionalidade de um incentivo fiscal de ICMS realizado à revelia do CONFAZ, é possível concluir que não seria possível conferir-lhe efeitos retroativos, pois o princípio da proteção à confiança legítima seria suficiente para que o Supremo Tribunal Federal modulasse os efeitos da decisão.

Isso porque a atuação do contribuinte nessa hipótese teria sido guiada pelo princípio da boa-fé objetiva, sendo razoável admitir que ele tivesse confiado na presunção de constitucionalidade da lei posteriormente declarada inconstitucional.

\footnotetext{
${ }^{50}$ Ibidem, p; 372.

51 Art. 146. A modificação introduzida, de ofício ou em conseqüência de decisão administrativa ou judicial, nos critérios jurídicos adotados pela autoridade administrativa no exercício do lançamento somente pode ser efetivada, em relação a um mesmo sujeito passivo, quanto a fato gerador ocorrido posteriormente à sua introdução.

${ }^{52}$ BRASIL. Presidência da República. Casa Civil. Subchefia de Assuntos Jurídicos. Lei no 5.172, de 25 de outubro de 1966. Disponível em: < http://www.planalto.gov.br/ccivil_03/leis/L5172Compilado.htm>. Acesso: 11 jan. 2017.

${ }^{53}$ TORRES, op.cit, p. 227-228.

${ }^{54}$ NABAIS, José Casalta. O dever fundamental de pagar impostos. Coimbra: Almedina, 1998, p. 408.

${ }^{55}$ Interessante notar que o Superior Tribunal de Justiça firmou jurisprudência, com base no princípio da boa-fé objetiva que deu ensejo a súmula $\mathrm{n}^{\circ} 509$, que impede a glosa de créditos de ICMS decorrente de nota fiscal oriunda de Estado onde há incentivo fiscal. Para aprofundamentos, conferem-se os seguintes precedentes: Súmula 509, PRIMEIRA SEÇÃO, julgado em 26/03/2014, DJe 31/03/2014; AgRg nos EDcl no AREsp 102.473/SP, Rel. Ministro BENEDITO GONÇALVES, PRIMEIRA TURMA, julgado em 26/06/2012, DJe 02/08/2012; AgRg no Ag 1239942/SP, Rel. Ministro ARNALDO ESTEVES LIMA, PRIMEIRA TURMA, julgado em 01/09/2011, DJe 09/09/2011; AgRg no AREsp 80.470/SP, Rel. Ministro HERMAN BENJAMIN, SEGUNDA TURMA, julgado em 12/06/2012, DJe 26/06/2012.
} 


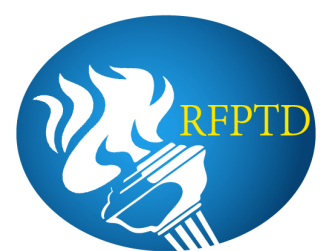

A confiança depositada no Estado pelos contribuintes que economizaram ICMS pautados em normas estaduais não chanceladas pelo CONFAZ não pode ser afetada pela conduta do próprio Estado com a cobrança retroativa dos valores economizados em face da declaração de inconstitucionalidade, fato esse que se revelaria de inconstitucionalidade muito mais explícita do que o que teria dado causa a declaração de inconstitucionalidade ${ }^{56}$.

Pensar de outra maneira seria o mesmo que admitir uma penalização injusta daqueles contribuintes que nada mais fizeram que seguir e confiar em parâmetros legais editados pelo próprio Estado. Além disso, seria o mesmo que legitimar uma política insana pela qual o Estado, com uma mão, atrai os investimentos privados e, com outra, os retira e cobra com juros e correção monetária, em inequívoco comportamento contraditório intolerável ${ }^{57}$.

$\mathrm{O}$ quadro fica ainda mais grave quando se trata de incentivos fiscais condicionados, ou seja, aqueles onde se exige alguma contrapartida por parte do contribuinte, os quais, pelo art. 178 do $\mathrm{CTN}^{58}$, não podem ser revogados ${ }^{59}$.

Em sentido oposto, no entanto, encontra-se, por exemplo, Alcides Jorge Costa, que argumenta que embora a lei concessora de incentivos estivesse, de fato, em vigor, dela se beneficiou apenas os contribuintes que assim desejaram, dadas as vantagens econômicas, caindo por terra o argumento da obediência à lei ${ }^{60}$.

Argumenta que todos sabiam, Estado e contribuintes, que os incentivos concedidos de forma unilateral eram inconstitucionais e que para assegurar a segurança jurídica a decisão

\footnotetext{
${ }^{56}$ MEDEIROS, Alberto. Inconstitucionalidade de benefícios fiscais unilaterais em matéria de ICMS e segurança jurídica dos contribuintes. In: Revista Dialética de Direito Tributário no 238. São Paulo, jul. 2015, p. 23.

57 Ibidem, p. 24.

58 “Art. 178 - A isenção, salvo se concedida por prazo certo e em função de determinadas condições, pode ser revogada ou modificada por lei, a qualquer tempo, observado o disposto no inciso III do art. 104".

${ }^{59}$ Recentemente, foi aprovado o Convênio CONFAZ $\mathrm{n}^{\circ} 42$, de 3 de maio de 2016, que permitiu a cobrança pelos Estados e Distrito Federal, de uma espécie de "pedágio de incentivo", através do qual o contribuinte ficaria obrigado a depositar em um fundo, o valor, no mínimo, de dez por cento do incentivo fiscal. As verbas seriam destinadas a um fundo de equilíbrio fiscal, destinado a manutenção do equilíbrio das finanças públicas.

Evidente que o mencionado dispositivo não pode ser aplicado aos incentivos físcais condicionados, sob pena de violação ao direito adquirido, que encontra proteção no art. $5^{\circ}$, XXXVI da Constituição, entendimento este amparado na súmula $n^{\circ} 544$ do Supremo Tribunal Federal, que determina: "Isenções tributárias concedidas, sob condição onerosa, não podem ser livremente suprimidas”.

Esse entendimento vem sendo mantido em julgados mais recentes, a exemplo de: "Ementa: Agravo Regimental em Recurso Extraordinário. Constitucional. Tributário. Isenção concedida e deferida a prazo certo. Livre supressão. Impossibilidade. Súmula 544 do STF. Alegada ofensa ao art. 97 da CF. Inexistência. Agravo improvido. I - O acórdão recorrido encontra-se em consonância com a jurisprudência desta Corte, no sentido de que a isenção tributária, quando concedida por prazo certo e mediante o atendimento de determinadas condições, gera direito adquirido ao contribuinte beneficiado. Incidência da Súmula 544 do STF. (...)." (RE 582926 AgR, Relator Ministro Ricardo Lewandowski, Primeira Turma, julgamento em 10.5.2011, DJe de 27.5.2011)

${ }^{60}$ COSTA, Alcides Jorge. Guerra fiscal e modulação dos efeitos das decisões do STF. In: In: Grandes questões atuais do direito tributário. $16^{\circ}$ volume. São Paulo: Dialética, 2012, p. 10.
} 


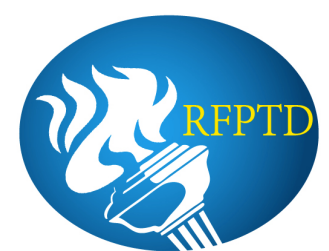

deveria ser ex tunc, pois do contrário os Estados continuarão com a ilegal prática, com confiança que, no futuro, a decisão que vier a ser proferida será modulada. Para ele, Estados e contribuintes tem culpa ${ }^{61}$.

A resposta a pergunta-problema não é fácil, mas entende-se que a razão está com aqueles que defendem a modulação dos efeitos da decisão, de modo que o contribuinte não pode ser cobrado, de forma retroativa, a devolver os valores relativos a incentivos fiscais de ICMS realizados sem autorização unânime do CONFAZ.

Isso porque deve ser observado o princípio da proteção a confiança legítima, sendo possível prever que o contribuinte confiou no Estado, que concedeu incentivo fiscal com aparente legalidade, pois previsto em lei e cuja presunção de constitucionalidade (até mesmo por ter passado no controle prévio de constitucionalidade) não pode ser ignorada.

A questão foi posta em discussão no Supremo Tribunal Federal na Ação Direta de Inconstitucionalidade $n^{\circ} 4481$, onde o Plenário, por maioria, utilizou a técnica da modulação dos efeitos para determinar que os efeitos da decisão, que reconheceu a inconstitucionalidade de lei estadual concessora de incentivos fiscais à revelia do CONFAZ, somente valeriam a partir da decisão, que foi proferida em 11/03/2015. Confere-se a ementa do julgamento:

\begin{abstract}
Ementa: I. TRIBUTÁRIO. LEI ESTADUAL QUE INSTITUI BENEFÍCIOS FISCAIS RELATIVOS AO ICMS. AUSÊNCIA DE CONVÊNIO INTERESTADUAL PRÉVIO. OFENSA AO ART. 155, $\S 2^{\circ}$, XII, g, DA CF/88. II. CONTROLE DE CONSTITUCIONALIDADE. MODULAÇÃO DOS EFEITOS TEMPORAIS. 1. A instituição de benefícios fiscais relativos ao ICMS só pode ser realizada com base em convênio interestadual, na forma do art. $155, \S 2^{\circ}$, XII, g, da CF/88 e da Lei Complementar $n^{\circ}$ 24/75. 2. De acordo com a jurisprudência do STF, o mero diferimento do pagamento de débitos relativos ao ICMS, sem a concessão de qualquer redução do valor devido, não configura benefício fiscal, de modo que pode ser estabelecido sem convênio prévio. 3. A modulação dos efeitos temporais da decisão que declara a inconstitucionalidade decorre da ponderação entre a disposição constitucional tida por violada e os princípios da boa-fé e da segurança jurídica, uma vez que a norma vigorou por oito anos sem que fosse suspensa pelo STF. A supremacia da Constituição é um pressuposto do sistema de controle de constitucionalidade, sendo insuscetível de ponderação por impossibilidade lógica. 4. Procedência parcial do pedido. Modulação para que a decisão produza efeitos a contatar da data da sessão de julgamento ${ }^{62}$.
\end{abstract}

A decisão sobre a modulação dos efeitos foi decorrente do voto do Ministro Relator Luís Roberto Barroso, com base nos seguintes argumentos:

\footnotetext{
${ }^{61}$ Ibidem, p. $10-11$.

${ }^{62}$ ADI 4481, Relator(a): Min. ROBERTO BARROSO, Tribunal Pleno, julgado em 11/03/2015, PROCESSO ELETRÔNICO DJe-092 DIVULG 18-05-2015 PUBLIC 19-05-2015.
}

Revista de Finanças Públicas, Tributação e Desenvolvimento - RFPTD, v. 6, n.6, 2018 


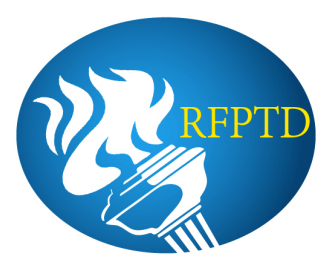

17. A respeito dos efeitos a serem produzidos pela presente decisão, é preciso ter em conta que o antigo relator desta ação aplicou ao caso o rito do art. 12 da Lei 9.868/1999, deixando, por isso, de apreciar o pedido de cautelar de forma imediata.

18. É certo que a jurisprudência do STF sobre o procedimento a ser observado para o deferimento de benefícios em matéria de ICMS é mais do que conhecida. Não gera grande surpresa a decisão ora proferida, no sentido da inconstitucionalidade da lei estadual. Por outro lado, a norma em exame vigorou por oito anos, com presunção de constitucionalidade, de modo que a atribuição efeitos retroativos à declaração de inconstitucionalidade geraria um grande impacto e um impacto injusto para os contribuintes.

19. Por isso, registro que a minha sugestão, nesses casos, é de que os relatores procurem se pronunciar sobre o pedido de cautelar no primeiro momento possível, trazendo em seguida a decisão ao plenário para referendo. Não tendo havido deferimento de cautelar, contudo, pareceme difícil afastar a modulação dos efeitos temporais da decisão.

20. Observo, por fim, que a modulação, no presente caso, decorre de um juízo de ponderação que não envolve o assim chamado princípio da supremacia da Constituição. A supremacia da Constituição é pressuposto do sistema de controle da constitucionalidade e, por consequência, é imponderável. A ponderação ocorre entre a disposição constitucional tida por violada e os princípios da boa-fé e da segurança jurídica 5. Pelas razões já expostas, entendo que devem prevalecer os últimos princípios, atribuindo-se eficácia a esta decisão a partir da data desta sessão". (Disponível em:

$<$ http://redir.stf.jus.br/paginadorpub/paginador.jsp?docTP=TP\&docID=8494796>.

Acesso: 13 set. 2016.)

O voto condutor do acórdão, portanto, levou em consideração princípios como o da boa-

fé e da segurança jurídica, além da presunção de constitucionalidade das leis, para modular os efeitos da decisão.

O voto vencido no caso em exame foi do Ministro Marco Aurélio, nos seguintes termos:

AÇÃO DIRETA DE INCONSTITUCIONALIDADE 4.481 PARANÁ O SENHOR MINISTRO MARCO AURÉLIO - Presidente, o pano de fundo é estreme de dúvidas: a guerra fiscal. O que havia quando da edição da lei? Jurisprudência pacificada do Supremo sobre a inviabilidade de outorga de benefício fiscal, sem o convênio previsto na Carta da República. Mas, não vinga no Brasil o império da lei, vinga no Brasil o critério de plantão, o interesse político, que não é o interesse político institucional, voltado ao avanço, à busca de dias melhores. Editou-se, em um Estado dos mais respeitáveis em termos de cultura, uma lei que, de forma escancarada - tanto que a decisão quanto à matéria de fundo mostrou-se unânime, não houve voz dissonante -, menosprezando inúmeros pronunciamentos do Supremo, implicou a guerra fiscal. Está ficando muito fácil editar diplomas legais à margem da Constituição Federal, porque depois, em passo seguinte, há o concerto do Supremo; mas concerto não com "s", o concerto com "c". Dá-se, naquele período, o dito pelo não dito, salva-se a lei em detrimento da Carta da República, como se esta tivesse ficado em suspenso no período, não vigorasse no território nacional. E me assusta muito que se vem, passo a passo, generalizando o instituto da modulação, a ponto de cogitar-se desse instituto quanto a algo que foi mais do que sinalizado - apenas não houve a edição de verbete de súmula pelo Supremo. Presidente, não se tem como deixar de pagar um preço que, a meu ver, é módico, por viver-se num Estado Democrático de Direito, que é o preço a direcionar à observância irrestrita dos ditames constitucionais, a menos que se diga que a Constituição não é rígida, é uma Constituição flexível, que pode ser colocada em segundo plano. Dir-se-á que foram beneficiados contribuintes. Esses contribuintes tiveram uma situação jurídica aperfeiçoada? Não, acabou de assentar o Supremo, de 


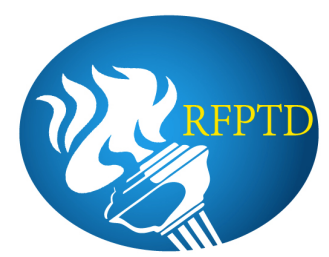

certificar o Supremo, no que colou à lei do Estado do Paraná a pecha de inconstitucional. O que a Carta da República protege, em cláusula pétrea, é a situação jurídica aperfeiçoada, e apenas se diz que a situação é aperfeiçoada quando harmônica com a ordem jurídica. E capitaneando essa ordem jurídica ainda se tem a muito pouco amada, por Estados, ante as conveniências governamentais reinantes, a Constituição Federal. Fico a imaginar em que caso se deixará de modular a decisão, se, num caso em que houve o desrespeito flagrante, frontal à Constituição, mais do que isso, a reiterados pronunciamentos do Supremo, é implementada a modulação. Não sei se sou compelido a pedir vênia para divergir, mas não vou pedir. É menoscabo à Carta da República editar uma lei como essa, em conflito evidente com a Constituição, já que a sujeição ao convênio unânime nela está em bom vernáculo, para chegar-se ao benefício, e, então, simplesmente, apostar-se na morosidade da Justiça, que, em um futuro próximo, acomodará a situação. Não se estimulam, dessa forma, os cidadãos em geral a respeitarem o arcabouço normativo constitucional em vigor. Ao contrário, em quadra muito estranha, incentiva-se a haver o desrespeito e, posteriormente, ter-se o famoso jeitinho brasileiro, dando-se o dito pelo não dito, o errado pelo certo. Não modulo, Presidente". (Disponível em:

$<$ http://redir.stf.jus.br/paginadorpub/paginador.jsp?docTP=TP\&docID=8494796>.

Acesso: 13 set. 2016.)

O Ministro vencido foi bastante crítico a decisão majoritária, chegando a afirmar que se trata de um "jeitinho brasileiro", argumentando que no momento da edição da lei a jurisprudência do Supremo Tribunal Federal já era pacífica no sentido de exigir a unanimidade pelo CONFAZ para a validade de incentivos fiscais de ICMS.

No entanto, como já visto, a possibilidade de modulação dos efeitos não é uma invenção brasileira, mas um desdobramento da teoria da anulabilidade desenvolvida por Kelsen e que é adotada em diversos países, a exemplo da Áustria, modelo que foi seguido por Turquia e Iuguslávia ${ }^{63}$.

$\mathrm{Na}$ Alemanha, apesar de adotar a teoria da nulidade, admite-se a declaração de inconstitucionalidade sem pronúncia de nulidade como técnica alternativa de decisão utilizável em todas as situações nas quais a declaração de nulidade se mostrasse inadequada ou intolerável para a segurança jurídica ${ }^{64}$, o que demonstra certo temperamento a teoria da nulidade tal como pensada por Marshall ${ }^{65}$.

Vale lembrar, como assevera Cappelleti ${ }^{66}$, que até mesmo nos Estados Unidos houve uma atenuação da teoria da nulidade, onde se construiu uma jurisprudência em matéria civil, no sentido de que se deve respeitar certos "efeitos consolidados" produzidos por atos fundados em

\footnotetext{
${ }^{63}$ CAPPELETTI, op. cit, p. 116.

${ }^{64}$ MENDES, Gilmar Ferreira. Controle abstrato de constitucionalidade: ADI, ADC e ADO: comentários à lei 9.868/99 - São Paulo: Saraiva, 2012, p. 461.

${ }^{65}$ Vide item 2.3.1.

${ }^{66}$ CAPPELLETI, op. cit., p. 122 - 124.
} 


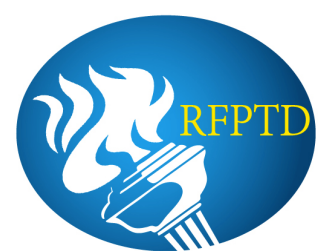

leis depois declaradas contrárias à Constituição, levando-se em consideração o fato de que, de outra maneira, se teriam graves repercussões sobre a paz social ${ }^{67}$.

Para Fernando Facury Scaff, no entanto, a modulação realizada pelo Supremo Tribunal Federal não foi suficiente. Ao comentar a proposta de súmula vinculante $n^{\circ} 69$ e sua possível modulação, ele defende que, por razões de segurança jurídica, seja o julgamento modulado pro futuro, com vigência "a partir do $1^{\circ}$ dia posterior a 12 meses de sua edição", o que permitirá que empresas afetadas organizem sua atividade empresarial, revendo sua estrutura de custos e a estratégia das decisões de investimento ${ }^{68}$.

É verdade que a modulação realizada pelo Supremo Tribunal Federal foi insuficiente, pois, como tem efeitos a partir do julgamento, fatalmente pegará muitos contribuintes de surpresa, que não terão tempo para adequar sua planilha de preços a essa nova realidade.

Contudo, a solução sugerida por Fernando Facury Scaff pode representar garantia ainda maior que aquela prevista na Constituição para proteção do contribuinte contra o aumento inesperado da carga tributária.

Acredita-se ser o caso de se tratar o assunto como se fosse uma revogação de incentivos fiscais, que por implicar, ainda que de modo indireto, em aumento de tributo, deve observância ao princípio da anterioridade, como vem decidindo o Supremo Tribunal Federal, consoante Informativo de Jurisprudência $n^{\mathrm{o}} 757^{69}$.

\footnotetext{
${ }^{67}$ Sobre o tema: SUPREME COURT OF THE UNITED STATES. Linkletter v. Walker, 381 U.S. 618, 1965. Disponível em: $<\mathrm{https} / /$ supreme.justia.com/cases/federal/us/381/618/case.htmlL > . Acesso: $27 \mathrm{dez}$, p. 2, 2016.

${ }^{68}$ SCAFF, Fernando Facury. A exigência de unanimidade pelo Confaz não foi recepcionada pela Constituição. In: SCAFF, Fernando Facury. Crônicas de direito financeiro: tributação, guerra fiscal e políticas públicas. $1^{\mathrm{a}}$ ed. São Paulo: Conjur Editorial, 2016, p. 202. Ver também: SCAFF, Fernando Facury. Guerra Fiscal e Súmula Vinculante: entre o Formalismo e o Realismo. ROCHA, Valdir de Oliveira. Grandes Questões Atuais do Direito Tributário, v. 18. São Paulo: Dialética, 2014. p. 90-115.

69، ICMS: revogação de benefício fiscal e princípio da anterioridade tributária

Configura aumento indireto de tributo e, portanto, está sujeita ao princípio da anterioridade tributária, a norma que implica revogação de benefício fiscal anteriormente concedido. Com base nessa orientação, a $1^{\mathrm{a}}$ Turma, por maioria, manteve decisão do Ministro Marco Aurélio (relator), que negara seguimento a recurso extraordinário, por entender que o acórdão impugnado estaria em consonância com o precedente firmado na ADI 2.325 MC/DF (DJU de 6.10.2006). Na espécie, o tribunal "a quo" afastara a aplicação — para o ano em que publicados — de decretos estaduais que teriam reduzido benefício de diminuição de base de cálculo do ICMS, sob o fundamento de ofensa ao princípio da anterioridade tributária. A Turma afirmou que os mencionados atos normativos teriam reduzido benefício fiscal vigente e, em consequência, aumentado indiretamente o aludido imposto, o que atrairia a aplicação do princípio da anterioridade. Frisou que a concepção mais adequada de anterioridade seria aquela que afetasse o conteúdo teleológico da garantia. Ponderou que o mencionado princípio visaria garantir que o contribuinte não fosse surpreendido com aumentos súbitos do encargo fiscal, o que propiciaria um direito implícito e inafastável ao planejamento. Asseverou que o prévio conhecimento da carga tributária teria como base a segurança jurídica e, como conteúdo, a garantia da certeza do direito. Ressaltou, por fim, que toda alteração do critério quantitativo do consequente da regra matriz de incidência deveria ser entendida como majoração do tributo. Assim, tanto o aumento de alíquota, quanto a redução de benefício, apontariam para o mesmo resultado, qual seja, o agravamento do encargo. Vencidos os Ministros Dias Toffoli e Rosa Weber, que proviam o agravo regimental. Após aduzirem que
} 


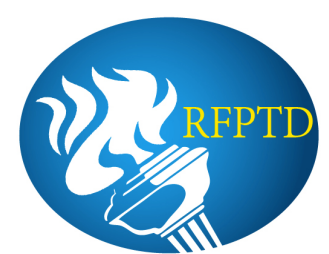

Da mesma forma, deve ser observado o princípio da noventena, previsto no art. 150, III, "b" da Constituição.

Para que fique claro: sabe-se da diferença entre a revogação e a anulação de um ato e que os institutos operam efeitos, via de regra, diferentes. O que se defende é que, dada as circunstâncias do caso, aplique-se a exceção da regra, para que a norma seja anulada sem efeitos retroativos e que para que seja preservado o princípio da confiança legítima, a modulação seja realizada pro futuro, observando-se os princípios da anterioridade e noventena.

Assim, seria possível chegar ao seguinte enunciado "que os efeitos da decisão sejam modulados pro futuro, com vigência a partir do exercício seguinte em que a ata de julgamento tenha sido publicada e somente depois de transcorrido noventa dias dessa publicação".

Elegeu-se a data da publicação da ata de julgamento como marco temporal, por ser o momento em que as decisões proferidas no controle concentrado de constitucionalidade passam a surtir efeitos, de acordo com a jurisprudência do próprio Supremo Tribunal Federal ${ }^{70}$.

\section{CONCLUSÕES}

No artigo foi possível verificar que o ordenamento jurídico brasileiro adotou uma posição intermediária a respeito dos efeitos temporais da declaração de inconstitucionalidade de uma lei.

Apesar de adotar, como regra, a teoria da nulidade, aproximando-se a teoria de Marshall, ao admitir a exceção da regra, em especial através da modulação dos efeitos da decisão, verificase uma aproximação a teoria da anulabilidade kelseniana.

benefícios fiscais de redução de base de cálculo se caracterizariam como isenção parcial, pontuavam que, de acordo com a jurisprudência do STF, não haveria que se confundir instituição ou aumento de tributos com revogação de isenções fiscais, uma vez que, neste caso, a exação já existiria e persistiria, embora com a dispensa legal de pagamento.

RE $564225 \mathrm{AgR} / \mathrm{RS}$, rel. Min. Marco Aurélio, 2.9.2014. (RE-564225)" (SUPREMO TRIBUNAL FEDERAL. Informativo de Jurisprudência $\quad \mathrm{n}^{\mathrm{o}} 757 . \quad$ Disponível el $<<$ http://www.stf.jus.br/arquivo/informativo/documento/informativo757.htm. Acesso: 01 mar. 2017.

70 SUPREMO TRIBUNAL FEDERAL. Rcl 6999 AgR, Relator(a): Min. TEORI ZAVASCKI, Tribunal Pleno, julgado em 17/10/2013, ACÓRDÃO ELETRÔNICO DJe-220 DIVULG 06-11-2013 PUBLIC 07-11-2013. Ver também: Rcl 2576, Relator(a): Min. ELLEN GRACIE, Tribunal Pleno, julgado em 23/06/2004, DJ 20-08-2004 PP00038 EMENT VOL-02160-01 PP-00105 RTJ VOL-00193-01 PP-00103. 


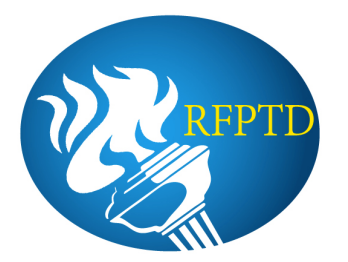

Ao analisar pergunta-problema fica clara a necessidade de se modular os efeitos da decisão no caso de incentivos fiscais fruto da guerra fiscal, como medida indispensável para se assegurar a observância do princípio da proteção à confiança legítima.

Entende-se, portanto, que contribuinte não pode ser cobrado, de forma retroativa, a devolver os valores relativos a incentivos fiscais de ICMS realizados sem autorização unânime do CONFAZ.

Aliás, constata-se que a modulação feita pelo Supremo Tribunal Federal na ADI 4441 foi insuficiente, pois é necessário um espaço de tempo entre a decisão e o início da cobrança do tributo, a fim de que as empresas se organizem e reformulem seus preços com base no novo custo tributário.

Entende-se, com apoio nos princípios constitucionais da anterioridade e noventena, que seria mais adequado que a decisão fosse modulada, de acordo com o seguinte enunciado: "que os efeitos da decisão sejam modulados pro futuro, com vigência a partir do exercício seguinte em que a ata de julgamento tenha sido publicada e somente depois de transcorrido noventa dias dessa publicação".

\section{REFERÊNCIAS BIBLIOGRÁFICAS}

ALEXY, Robert. Teoria dos direitos fundamentais (tradução Virgilio Afonso da Silva) - $5^{\text {a }}$ edição. São Paulo: Malheiros, 2008.

ÁVILA, Humberto. Segurança jurídica: entre permanência, mudança e realização no direito tributário - 2 ed. - São Paulo: Malheiros, 2012.

BANDEIRA DE MELLO, Celso Antônio. Segurança jurídica, boa-fé e confiança legítima. In: BENEVIDES, Maria Victoria de Mesquita; BERCOVICI, Gilberto; MELO, Claudineu de (org.). Direitos humanos, democracia e república. Homenagem a Fábio Konder Comparato. São Paulo: Quartier Latin, 2009.

BARBOSA, Rui. Os actos inconstitucionais do Congresso e do Executivo ante a justiça federal. Companhia Impressora: Capital Federal, 1893.

BARROSO, Luís Roberto. O controle de constitucionalidade no direito brasileiro $-2^{\mathrm{a}}$ ed - São Paulo: Saraiva, 2006.

CANOTILHO, José Joaquim Gomes. Direito Constitucional e Teoria da Constituição, Coimbra, Livraria Almedina, 2000. 


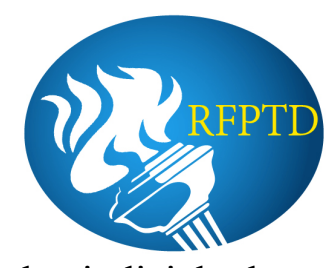

CAPPELLETTI, Mauro. O controle judicial de constitucionalidade das leis no direito comparado. Tradução de Aroldo Plínio Gonçalves. Porto Alegre, Fabris, 1984.

CARDOSO, Breno Lobato. Direitos fundamentais e tributação. In: Revista Fórum de Direito Tributário - ano 13 - n. 78. Nov. / Dez. 2015 - Belo Horizonte, p. 173-187.

CARRAZA, Roque Antonio. ICMS - 12a Ed - São Paulo: Malheiros, 2007.

CARVALHO, Paulo de Barros. Direito tributário: fundamentos jurídicos da incidência - 9 ed. São Paulo: Saraiva, 2012.

, Paulo de Barros. A concessão de isenções, incentivos ou benefícios fiscais no âmbito do ICMS. In: CARVALHO, Paulo de Barros. MARTINS, Ives Gandra da Silva. Guerra fiscal: reflexões sobre a concessão de benefícios no âmbito do ICMS - $2^{\text {a }}$ ed. - São Paulo: Noeses, 2014.

, Paulo de Barros. O princípio da segurança jurídica em matéria tributária. Disponível em: $\quad<<$ http://www.revistas.usp.br/rfdusp/article/download/67584/70194>>. Acesso: 04 jan. 2017.

COSTA, Alcides Jorge. Guerra fiscal e modulação dos efeitos das decisões do STF. In: In: Grandes questões atuais do direito tributário. $16^{\circ}$ volume. São Paulo: Dialética, 2012.

KELSEN, Hans. Teoria pura do direito (tradução João Baptista Machado) - $6^{\mathrm{a}}$ ed. - São Paulo: Martins Fontes, 1998.

LUÑO, Antonio-Enrique Pérez. La seguridade jurídica: uma garantia del derecho y la justicia. Disponível em: <<http://e-spacio.uned.es/fez/eserv/bibliuned:BFD-2000-15-48A09575/PDF $>>$. Acesso. 04 jan. 2017.

MACHADO, Hugo de Brito. Proibição da guerra fiscal e a redução das desigualdades regionais. In: Grandes questões atuais do direito tributário. 15º volume. São Paulo: Dialética, 2011.

. Declaração de inconstitucionalidade e direito intertemporal. In: Revista Dialética de Direito Tributário ${ }^{0}$ 57, p. 72-87.

MEDEIROS, Alberto. Inconstitucionalidade de benefícios fiscais unilaterais em matéria de ICMS e segurança jurídica dos contribuintes. In: Revista Dialética de Direito Tributário ${ }^{\circ} 238$. São Paulo, jul. 2015.

MENDES, Gilmar Ferreira. Controle abstrato de constitucionalidade: ADI, ADC e ADO: comentários à lei 9.868/99 - São Paulo: Saraiva, 2012.

NABAIS, José Casalta. O dever fundamental de pagar impostos. Coimbra: Almedina, 1998.

SCAFF, Fernando Facury. MAUÉS, Antonio G. Moreira. Justiça constitucional e tributação São Paulo: Dialética, 2005. 


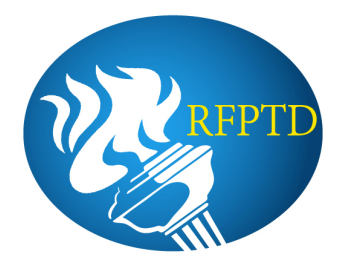

SCAFF, Fernando Facury. Novas batalhas da guerra fiscal e a emenda 87. In: SCAFF, Fernando Facury. Crônicas de direito financeiro: tributação, guerra fiscal e políticas públicas. $1^{\mathrm{a}}$ ed. São Paulo: Conjur Editorial, 2016, p. 206-210.

, Fernando Facury. A responsabilidade tributária e a inconstitucionalidade da guerra fiscal. In: Grandes questões atuais do direito tributário. $15^{\circ}$ volume. São Paulo: Dialética, 2011.

, Fernando Facury. Guerra Fiscal e Súmula Vinculante: entre o Formalismo e o Realismo. ROCHA, Valdir de Oliveira. Grandes Questões Atuais do Direito Tributário, v. 18. São Paulo: Dialética, 2014. p. 90-115.

SUPERIOR TRIBUNAL DE JUSTIÇA. AgRg nos EDcl no AREsp 102.473/SP, Rel. Ministro BENEDITO GONÇALVES, PRIMEIRA TURMA, julgado em 26/06/2012, DJe 02/08/2012.

AgRg no Ag 1239942/SP, Rel. Ministro ARNALDO ESTEVES LIMA, PRIMEIRA TURMA, julgado em 01/09/2011, DJe 09/09/2011.

AgRg no AREsp 80.470/SP, Rel. Ministro HERMAN BENJAMIN, SEGUNDA TURMA, julgado em 12/06/2012, DJe 26/06/2012.

Súmula 509, PRIMEIRA SEÇÃO, julgado em 26/03/2014, DJe 31/03/2014.

SUPREME COURT OF THE UNITED STATES. Willian Marbury v. James Madison, Secretary of State of the United States. Februrary, 1803. Disponível em: $<<$ http://law2.umkc.edu/faculty/projects/ftrials/conlaw/marbury.HTML $>>$. Acesso: 22 dez. 2016.

Linkletter v. Walker, 381 U.S. 618, 1965. Disponível em:

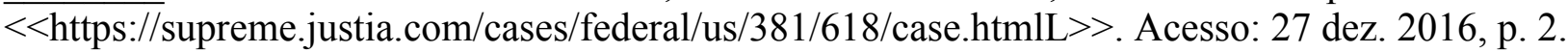

SUPREMO TRIBUNAL FEDERAL. ADI 652, Relator(a): Min. CELSO DE MELLO, Tribunal Pleno, julgado em 02/04/1992, DJ 02-04-1993 PP-05615 EMENT VOL-01698-03 PP-00610 RTJ VOL-00146-02 PP-00461.

ADI 4481, Relator(a): Min. ROBERTO BARROSO, Tribunal Pleno, julgado em 11/03/2015, PROCESSO ELETRÔNICO DJe-092 DIVULG 18-05-2015 PUBLIC 19-05-2015.

Andamento processual da ADI 2258. Disponível em: $<<$ http://www.stf.jus.br/portal/processo/verProcessoAndamento.asp?incidente $=1835254>>$. Acesso: 25 jan., 2017.

ARE 946671 AgR, Relator(a): Min. LUIZ FUX, Primeira Turma, julgado em $\overline{14 / 10 / 2016}$, PROCESSO ELETRÔNICO DJe-234 DIVULG 03-11-2016 PUBLIC 04-11-2016.

. RE 607058 AgR, Relator(a): Min. ROBERTO BARROSO, Primeira Turma, julgado em 30/09/2016, PROCESSO ELETRÔNICO DJe-221 DIVULG 17-10-2016 PUBLIC 18-102016. 


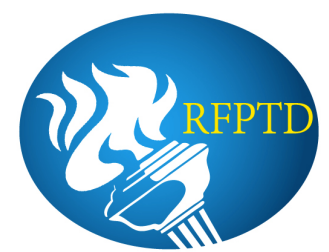

. ARE 974338 AgR, Relator(a): Min. EDSON FACHIN, Primeira Turma, julgado em 28/10/2016, PROCESSO ELETRÔNICO DJe-244 DIVULG 17-11-2016 PUBLIC 18-11-2016.

. Informativo de Jurisprudência $\mathrm{n}^{\mathrm{o}}$ 629. Disponível em:

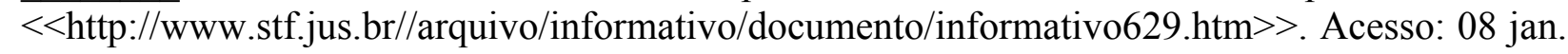
2016.

Informativo de Jurisprudência $\mathrm{n}^{\mathrm{o}}$ 633. Disponível em : $\quad<<$ http://www.stf.jus.br/portal/jurisprudencia/listarJurisprudencia.asp?s1=\%28incentivo + fiscal $+\mathrm{e}+\mathrm{i}$ cms\%29\&base=baseInformativo\&url=http://tinyurl.com/hzvw425>>. Acesso: 14 mar. 2016.

Informativo de Jurisprudência $\mathrm{n}^{\mathrm{o}}$ 755. Disponível em $: \quad<<$ http://www.stf.jus.br/portal/jurisprudencia/listarJurisprudencia.asp?s1=\%28incentivo + fiscal $+\mathrm{e}+\mathrm{i}$ cms\%29\&base=baseInformativo\&url=http://tinyurl.com/hzvw425>>. Acesso: 14 mar. 2016.

Proposta de súmula vinculante $\mathrm{n}^{\mathrm{o}}$ 69. Disponível em:

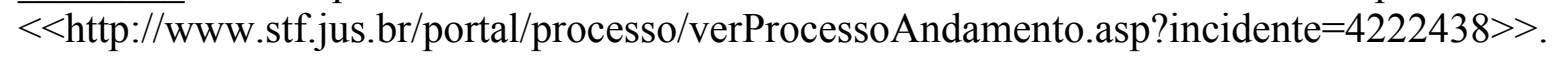
Acesso: 08 jan. 2016.

. Rcl 1880 AgR, Relator(a): Min. MAURÍCIO CORRÊA, Tribunal Pleno, julgado em $\overline{07 / 11 / 2002}$, DJ 19-03-2004 PP-00017 EMENT VOL-02144-02 PP-00284.

. Rcl 8168, Relator(a): Min. ELLEN GRACIE, Relator(a) p/ Acórdão: Min. EDSON

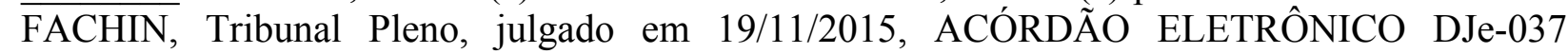
DIVULG 26-02-2016 PUBLIC 29-02-2016.

. Rcl 19541 AgR, Relator(a): Min. ROBERTO BARROSO, Primeira Turma, julgado em 07/06/2016, PROCESSO ELETRÔNICO DJe-128 DIVULG 20-06-2016 PUBLIC 21-062016.

. Rcl 21884 AgR, Relator(a): Min. EDSON FACHIN, Primeira Turma, julgado em 15/03/2016, PROCESSO ELETRÔNICO DJe-066 DIVULG 08-04-2016 PUBLIC 11-04-2016.

. Rcl 21756 AgR, Relator(a): Min. EDSON FACHIN, Primeira Turma, julgado em $\overline{23 / 02 / 2016}$, PROCESSO ELETRÔNICO DJe-047 DIVULG 11-03-2016 PUBLIC 14-03-2016.

. RE 78533, Relator(a): Min. FIRMINO PAZ, Relator(a) p/ Acórdão: Min. DÉCIO MIRANDA, Segunda Turma, julgado em 13/11/1981, DJ 26-02-1982 PP-01290 EMENT VOL01243-01 PP-00090 RTJ VOL-00100-03 PP-01086.

. RE 86056, Relator(a): Min. RODRIGUES ALCKMIN, Primeira Turma, julgado em 31/05/1977, DJ 01-07-1977 PP-04452 EMENT VOL-01063-09 PP-03075.

. RE 122202, Relator(a): Min. FRANCISCO REZEK, Segunda Turma, julgado em 10/08/1993, DJ 08-04-1994 PP-07243 EMENT VOL-01739-05 PP-00945) 
TORRES, Heleno Taveira. Direito constitucional tributário e segurança jurídica: metódica da segurança jurídica do sistema constitucional tributário - São Paulo: Editora Revista dos Tribunais, 2011.

VELOSO, Zeno. Controle jurisdicional de constitucionalidade: atualizado conforme as Leis 9.868 de 10.11.1999 e 9.882 de 03.12.1999 - 3 ed. - Belo Horizonte: Del Rey Editora, 2003. 